\title{
Performance Evaluation and Adaptation of Food Barley (Hordeum Vulgare L.) Varieties in the Highlands of North Gondar Ethiopia
}

\author{
Asaye Birhanu*, Zeynu Tahir, Manye Tilahun, Mellie Tilahun, Abebe Hailu \\ Gondar Agricultural Research Center, Gondar, Ethiopia \\ Email address: \\ asayeb12@gmail.com (A. Birhanu) \\ ${ }^{*}$ Corresponding author \\ To cite this article: \\ Asaye Birhanu, Zeynu Tahir, Manye Tilahun, Mellie Tilahun, Abebe Hailu. Performance Evaluation and Adaptation of Food Barley \\ (Hordeum Vulgare L.) Varieties in the Highlands of North Gondar Ethiopia. American Journal of Agriculture and Forestry. \\ Vol. 8, No. 6, 2020, pp. 252-257. doi: 10.11648/j.ajaf.20200806.13
}

Received: September 29, 2020; Accepted: November 2, 2020; Published: November 27, 2020

\begin{abstract}
In Ethiopia, barley is also one of the oldest cultivated crops and currently it is the fifth most important cereal crop next to maize, tef, sorghum, and wheat and the study was conducted at Debark, Dabat and Wogera in 2014/15 main season with the objectives of identify high yielder food barley varieties using seven improved food barley varieties including local check in Randomized Complete Block Design with three replications. At Debark, the analysis of variance revealed highly significant difference $(\mathrm{p} \leq 0.01)$ among treatment means for days to heading, plant height and thousand seed weight. Significant difference at $(\mathrm{p} \leq 0.05)$ also observed among treatments for Maturity days, spike length, biomass and grain yield. The mean grain yield ranged from $3403 \mathrm{~kg} / \mathrm{ha}-5143 \mathrm{~kg} / \mathrm{ha}$. Highest mean grain yield was recorded from variety HB-1307 (5143kg/ha), EH1493 (4636kg/ha) CROSS41/98 (4184kg/ha) and lowest mean grain yield was recorded from variety AGEGNEHU $(3403 \mathrm{~kg} / \mathrm{ha})$. At Dabat, the analysis of variance showed that significant difference $(\mathrm{p} \leq 0.05)$ for days to maturity, seeds per spike and thousand seed weight. The rest parameters exhibited non-significant difference among varieties. At Wogera, the analysis of variance showed highly significant difference at $(\mathrm{p} \leq 0.01)$ among tested varieties for days to maturity, spike length, seeds per spike, thousand seed weight and grain yield. Longest maturity days were recorded from variety CROSS-41/98 (124 days), while shortest maturity days were recorded from variety AGEGNEHU (112 days). The mean grain yield ranged from $2015 \mathrm{~kg} / \mathrm{ha}-5008 \mathrm{~kg} / \mathrm{ha}$. At Wogera highest mean grain yield was recorded from variety HB-1307 (5008kg/ha) followed by CROSS41/98 (4416kg/ha). Over locations combined analysis of variances showed highly significant difference at $(\mathrm{p} \leq 0.01)$ among varieties for all yield and yield components except days to heading. The interaction of location by variety indicated that significant effect on biomass and grain yield. The rest yield components not affected by the interaction of genotype by location. Over location grain yield results ranged from $3641-4680 \mathrm{~kg} / \mathrm{ha}$. Lowest and highest grain yield were recorded on Local check $(3641 \mathrm{~kg} / \mathrm{ha})$ and HB-1307 (4680kg/ha), respectively. Therefore, HB-1307 and CROSS 41/98 recommended for seed production at highland areas of north Gondar and similar agro ecologies.
\end{abstract}

Keywords: Barley, Districts, Grain Yield, Varieties

\section{Introduction}

Barley (Hordeum vulgare L.) has a long history as a domesticated crop, as one of the first to be adopted for cultivation and the crop is now virtually produced worldwide [15]. In Ethiopia, barley is also one of the oldest cultivated crops [9] and currently, it is the fifth most important cereal crop next to maize, tef, sorghum, and wheat with total area overage of over 0.94 million hectares of land [3]. Barley can be grown in the highlands, on steep slopes, eroded lands, with low inputs and it is major crop grown by highland farmers above $1800 \mathrm{~m}$ mainly under rain fed condition [4].

The total area covered by barley in Amhara region is about 339,689 hectares with a total production of $633,115.4$ tons and its productivity is (1.86 ton/ha) is below the national average of 2.07 ton/ha [5]. Barley is a staple food for 
highlanders and it is used in forms of food such as "injera", bread, soup, porridge, alcoholic and non-alcoholic drinks. It has great importance in social and food habit of the people However, barley production in Ethiopia especially in Amhara region practiced with little or no external inputs in the highland altitudes. However, productivity of food barley in North Gondar is low 1.3 ton $/ \mathrm{ha}^{-1}$ compared to regional average of Amhara 18.6 quintal/ha [3]. So far, no efforts have been made in promoting newly released food barley in North Gondar even though there is great potential in the highlands of the zone. Identification of adaptable variety minimizes the magnitude of scale or rank shift of their performance across or specific environment [6-8]. Thus, the present study was conducted to introduce and compare the performance of released food barely varieties for their adaptability and to recommend a suitable one for farmers of North Gondar of Ethiopia and similar agro-ecologies.

\section{Materials and Methods}

The experiment were conducted at Debark, Dabat and Wogera in 2014/15 main cropping season. Debark site is located at $13.13166 \mathrm{Nand} 37.899121 \mathrm{E}$. It is a trial site of Gondar Agricultural Research Center located at an altitude of 2885 m.a.s.l with annual average rainfall of $974 \mathrm{~mm}$ most of which falling between April and September having peaks in July and August. The temperature ranges from $8.6^{\circ} \mathrm{C}$ to 19.8
${ }^{0} \mathrm{c}$ and the soil type is classified as cambisol. Dabat site is located at $12.93178 \mathrm{Nand} 37.74412 \mathrm{E}$. It is a trial site of Gondar Agricultural Research Center located at an altitude of 2628 m.a.s.l with annual average rainfall of $758 \mathrm{~mm}$ ? most of which falling between April and September having peaks in July and August. Average temperature is $16.6^{\circ} \mathrm{C}$ and the soil type is classified as cambisol. Wogera is located at 12.82254Nand 37.70317E. It is farmer's field located at an altitude of 2790 m.a.s.l. Soil type is classified as cambisol.

Six improved food barley varieties including local check were evaluated and compared for their yield and other agronomic performance. The trial was laid out on Randomized Complete Block Design with three replications. Each experimental plot had six rows of 2.5 meter length and 1.2 meter width. The gross and harvestable plot size was $2.5 \mathrm{~m} * 1.2 \mathrm{~m}\left(3 \mathrm{~m}^{2}\right)$ and $0.8 \mathrm{~m} * 2.5 \mathrm{~m}\left(2 \mathrm{~m}^{2}\right)$, respectively. The spacing between rows, plots and blocks was $0.2 \mathrm{~m}, 0.5 \mathrm{~m}$ and $1 \mathrm{~m}$, respectively. Seed Rate of $85 \mathrm{~kg} / \mathrm{ha}$ was used. The fertilizer was applied at the rate of $100 \mathrm{Kg} / \mathrm{ha}$ UREA and $100 \mathrm{~kg} / \mathrm{ha}$ DAP. Half of the total UREA and fully DAP applied at the time of planting while the remaining UREA was applied at the time of tillering. Agronomic data were taken from the central four rows. Weeding and other agronomic practice were done as required. Analysis of variance was computed using the SAS statistical software [12].

Table 1. Description of Experimental Materials.

\begin{tabular}{|c|c|c|c|c|}
\hline Varieties & Year of released & Released centers & Altitude range (m.a.s.l) & Rain fall (mm) \\
\hline MISCAL -21 & - & - & - & - \\
\hline ESTAYISH & 2004 & SRARC & $2600-3000$ & $900-1200$ \\
\hline AGEGNEHU & 2007 & SRARC & $2006-3000$ & $900-1200$ \\
\hline HB-1307 & 2006 & HARC & $2000-3000$ & $700-1000$ \\
\hline EH-1493 & 2012 & HARC & $2300-2800$ & $700-1000$ \\
\hline CROSS 41/98 & 2012 & HARC & $2000-2600$ & $700-1000$ \\
\hline LOCAL CHECK & - & - & - & - \\
\hline
\end{tabular}

Source: - Different National and Regional Research Centers.

\section{Results and Discussions}

\subsection{At Debark District}

The analysis of variance revealed that highly significant difference $(\mathrm{p} \leq 0.01)$ among treatment means for days to heading, plant height and thousand seed weight. Similar results on the previous studies in the genetic variability in barley genotypes indicated that a significant difference exist for many of the traits like days to heading, plant height and thousand seed weight [13]. Significant difference $(p \leq 0.05)$ also observed among treatments for Maturity days, spike length, Grain yield and biomass (Table 2). Mean of Days to heading ranged from 93-101days. Local check and AGEGNEHU start heading and matured earlier than the other tested varieties. Longest maturity days were recorded from variety EH-1493 (168 days) and the shortest maturity days were recorded from variety AGEGNEHU (151 days). The plant height ranged from $100-114.1 \mathrm{~cm}$. Local variety is the tallest and Miscal-21 is the shortest among the tested varieties. The longest spike length recorded from local variety $(9.5 \mathrm{~cm})$ and shortest also recorded from variety AGEGNEHU $(7.3 \mathrm{~cm})$ among tested varieties. In addition to this, the highest thousand seed weight recorded from local variety; however, low biomass yield was recorded from local variety among tested varieties (Table 2 ).

The mean grain yield performance ranged from $3403 \mathrm{~kg} / \mathrm{ha}-5143 \mathrm{~kg} / \mathrm{ha}$. The highest mean grain yield was recorded from variety HB-1307 $(5143 \mathrm{~kg} / \mathrm{ha})$, EH-1493 (4636kg/ha) CROSS-41/98 (4184kg/ha) and the lowest mean grain yield was recorded from variety AGEGNEHU $(3403 \mathrm{~kg} / \mathrm{ha})$. From the results early matured varieties yield performance were low as compared to late matured varieties. In general, at Debark, variety HB-1307, EH-1493 and CROSS-41/98 have better yield performance among tested varieties. In the same way highest grain yield were obtained from HB- 1307 at both locations giving 4241 and $4328.5 \mathrm{~kg}$ ha-1 at Kurfa chale and Kersa in Ethiopia respectively [11]. 
The top yielder varieties showed yield advantages of $38.6 \%, \quad 24.9 \%$ and $12.7 \%$ over the local variety.

Table 2. The mean performance of yield and yield related traits of improved Food barley varieties during 2014 main season at DEBARK district, North Gondar.

\begin{tabular}{|c|c|c|c|c|c|c|c|c|}
\hline \multicolumn{9}{|l|}{ Mean values } \\
\hline Treatments & DHA & DMA & PLH & SPL & SPS & BMA & TSW & GYLD \\
\hline Miscal -21 & $96^{\mathrm{c}}$ & $159^{\mathrm{abc}}$ & $100^{\mathrm{b}}$ & $8.5^{\mathrm{ab}}$ & 37 & $9.7^{\mathrm{a}}$ & $52.4^{\mathrm{a}}$ & $3603^{b}$ \\
\hline Estayish & $100^{\mathrm{ab}}$ & $155^{\mathrm{bc}}$ & $113.5^{\mathrm{a}}$ & $8.8^{\mathrm{ab}}$ & 41.6 & $9.7^{\mathrm{a}}$ & $42^{\mathrm{d}}$ & $3676^{\mathrm{b}}$ \\
\hline HB1307 & $98^{\mathrm{bc}}$ & $162^{\mathrm{ab}}$ & $111.4^{\mathrm{a}}$ & $8.5^{\mathrm{ab}}$ & 38.3 & $10.6^{\mathrm{a}}$ & $48.7^{\mathrm{b}}$ & $5143^{\mathrm{a}}$ \\
\hline EH1493 & $101^{\mathrm{a}}$ & $168^{\mathrm{a}}$ & $110.9^{\mathrm{a}}$ & $8.6^{\mathrm{ab}}$ & 38.3 & $10.4^{\mathrm{a}}$ & $45.4^{\mathrm{c}}$ & $4636^{\mathrm{ab}}$ \\
\hline Cross 41/98 & $101^{\mathrm{a}}$ & $158^{\mathrm{abc}}$ & $108^{\mathrm{a}}$ & $8.3^{\mathrm{ab}}$ & 41.3 & $10.1^{\mathrm{a}}$ & $42.1^{\mathrm{d}}$ & $4184^{\mathrm{ab}}$ \\
\hline MEAN & 97 & 158 & 109.9 & 8.5 & 37.9 & 9.4 & 46.7 & 4051 \\
\hline $\mathrm{CV}$ & 2.3 & 4.2 & 3.4 & 2.2 & 12.6 & 15.4 & 3.2 & 18.3 \\
\hline LSD & 2 & 11 & 6.5 & 1.5 & 8.5 & 2.6 & 2.6 & 1316 \\
\hline Treatment & $* *$ & $*$ & $* *$ & $*$ & Ns & $*$ & $* *$ & $*$ \\
\hline
\end{tabular}

*and ** denote significant difference at $\mathrm{P}<0.05$ and $\mathrm{P}<0.01$, respectively. NS $=$ Non significant. DHA=Days to heading, DMA $=\mathrm{Days}$ to maturity, $\mathrm{PLH}=\mathrm{Plant}$ height, $\mathrm{SPL}=$ Spike length, $\mathrm{SPS}=$ Seeds per spike, BMA=Biomass, TSW=Thousand seed weight and GYLD=Grain yield.

\subsection{At Dabat District}

The analysis of variance showed that significant difference $(p<0.05)$ among treatments for days to maturity, grain per spike and thousand grain weight. The rest parameters showed non-significant difference among varieties (Table 2). The longest and shortest maturity days were recorded from variety ESTAYSH (122) and AGEGNEHU (111), respectively. Among the varieties highest numbers of grains per spike were recorded from variety ESTAYSH (49.9) and the lowest were recorded from variety MISCAL-21 (25). On the other hand, variety MISCAL-21 exhibited maximum thousand grain weight $(46 \mathrm{gm})$. Minimum thousand grain weight was recorded from variety EH1493 (35gm). Even though the analysis of variance indicated that non-significant difference among varieties, but variety ESTAYSH and
CROSS $41 / 98$ were high yielder $(4871 \mathrm{~kg} / \mathrm{ha}$ and $4177 \mathrm{~kg} / \mathrm{ha})$, respectively. Their yield advantages were $40 \%$ and $20.5 \%$, over the local check respectively. This might be variation between the two environments. Food barley varieties used in the present study had diverse genetic composition and as a consequence produced results in the parameters studied. Overall, the variation in plant height, days to maturity, spike length, seed per spike and grain yield observed were due to differences among the variety. However, the variation observed in the parameters studied compared to other location is environmental. Tahir et al. reported that plant height is genetically as well as environmental controlled factor [14]; however, the selection of proper crop cultivar manages the influence of environment. Therefore, as a specific recommendation these two varieties are recommended for DABAT areas and similar agro ecologies.

Table 3. The mean performance of yield and yield related traits of improved Food barley varieties during 2014 main season at DABAT district, North Gondar.

\begin{tabular}{|c|c|c|c|c|c|c|c|c|}
\hline \multicolumn{9}{|l|}{ Mean values } \\
\hline Varieties & DHA & DMA & PLH (cm) & SPL (cm) & SPS & BMA (kg) & TSW (gm) & GYLD (kg/ha) \\
\hline Miscal 21 & 70 & $117^{\mathrm{ab}}$ & 91 & 8.2 & $25^{c}$ & 10.7 & $46^{\mathrm{a}}$ & 3352 \\
\hline Estayish & 69 & $122^{\mathrm{a}}$ & 101 & 7.3 & $49.9^{\mathrm{a}}$ & 13.2 & $38^{\mathrm{bc}}$ & 4871 \\
\hline Agegnehu & 65 & $111^{\mathrm{b}}$ & 92 & 7.2 & $41.4^{\mathrm{ab}}$ & 12.5 & $36.3^{c}$ & 3394 \\
\hline HB-1307 & 64 & $118^{\mathrm{ab}}$ & 98 & 7.8 & $32^{\mathrm{bc}}$ & 13.2 & $41^{\mathrm{abc}}$ & 3888 \\
\hline EH-1493 & 63 & $116^{\mathrm{ab}}$ & 97 & 7.2 & $46.6^{\mathrm{ab}}$ & 13.5 & $35.2^{\mathrm{c}}$ & 4120 \\
\hline Cross 41/98 & 67 & $121^{\mathrm{a}}$ & 104 & 7.3 & $36^{\mathrm{abc}}$ & 14.5 & $39^{\mathrm{bc}}$ & 4177 \\
\hline MEAN & 66 & 117 & 97.5 & 7.6 & 37.6 & 13 & 39.9 & 3895.9 \\
\hline $\mathrm{CV} \%$ & 9.5 & 10.6 & 7.9 & 13.8 & 23.7 & 17.6 & 9.5 & 16.4 \\
\hline LSD & 11 & 8 & 14 & 1.9 & 16 & 4.1 & 6.7 & 1136 \\
\hline Treatment & ns & $*$ & ns & ns & $*$ & ns & $*$ & ns \\
\hline
\end{tabular}

*and $* *$ denote significant difference at $\mathrm{P}<0.05$ and $\mathrm{P}<0.01$, respectively. NS $=$ Non significant. DHA=Days to heading, DMA $=\mathrm{Days}$ to maturity, $\mathrm{PLH}=\mathrm{Plant}$ height, $\mathrm{SPL}=$ Spike length, $\mathrm{SPS}=$ Seeds per spike, BMA=Biomass, TSW=Thousand seed weight and GYLD=Grain yield.

\subsection{At Wogera District}

The analysis of variance showed highly significant difference at $(p \leq 0.01)$ among tested varieties for days to maturity, spike length, seeds per spike, thousand seed weight and grain yield. The shortest days to heading recorded for variety AGEGNEHU (Table 4). Maturity days were ranged from 112-124days. The longest maturity days were recorded from variety CROSS-41/98 (124 days), whereas the shortest maturity days were recorded from variety Agegnehu (112 days). Therefore, variety AGENGEHU matured earlier than other tested varieties. The mean plant height ranged from $106-114.2 \mathrm{~cm}$. Local variety is the tallest, while Miscal-21 is the shortest among the tested varieties (Table 4). The seeds per spike ranged from 24-50.6. The highest numbers of seeds 
[per spike were recorded from variety ESTAYSH, whereas the lowest number of seeds per spike was recorded from local variety (Table 4). The mean grain yield ranged from $2015 \mathrm{~kg} / \mathrm{ha}-5008 \mathrm{~kg} / \mathrm{ha}$. The highest mean grain yield was recorded from variety HB-1307 $(5008 \mathrm{~kg} / \mathrm{ha})$ followed by
CROSS-41/98 (4416kg/ha), whereas, the lowest mean grain yield was recorded from variety ESTAYSH $(2015 \mathrm{~kg} / \mathrm{ha})$. Therefore, variety HB-1307 and CROSS-41/98 well adapted and high yielder and recommended for Wogera area and similar agro ecologies.

Table 4. The means performance of yield and yield related traits of improved Food barley varieties during 2014 main season at WEGERA district, North Gondar.

\begin{tabular}{|c|c|c|c|c|c|c|c|c|}
\hline \multicolumn{9}{|l|}{ Mean values } \\
\hline Varieties & DHA & DMA & PLH & SPL & SPS & BMA & TSW & GYLD \\
\hline Miscal 21 & 83 & $123^{\mathrm{a}}$ & $106.0^{c}$ & $7.4^{\mathrm{cd}}$ & $25.8^{\mathrm{c}}$ & $12.5^{\mathrm{ab}}$ & $46.4^{a}$ & $4059^{\mathrm{abc}}$ \\
\hline Estayish & 81 & $122^{\mathrm{a}}$ & $108.7^{\mathrm{bc}}$ & $8.6^{\mathrm{ab}}$ & $50.6^{\mathrm{a}}$ & $8.6^{\mathrm{c}}$ & $34.9^{c}$ & $2051^{d}$ \\
\hline Agegnehu & 77 & $112^{\mathrm{b}}$ & $107.9^{\mathrm{bc}}$ & $6.2^{\mathrm{e}}$ & $41^{\mathrm{ab}}$ & $13.3^{\mathrm{ab}}$ & $34.9^{\mathrm{c}}$ & $4382^{\mathrm{ab}}$ \\
\hline HB1307 & 71 & $121^{\mathrm{a}}$ & $114.3^{\mathrm{a}}$ & $6.6^{\mathrm{de}}$ & $40^{\mathrm{ab}}$ & $15^{\mathrm{a}}$ & $41.2^{\mathrm{b}}$ & $5008^{\mathrm{a}}$ \\
\hline EH1493 & 74 & $122^{\mathrm{a}}$ & $111.4^{\mathrm{ab}}$ & $7.7^{\mathrm{bc}}$ & $43^{\mathrm{ab}}$ & $10.8^{\mathrm{bc}}$ & $32.3^{d}$ & $3202^{c}$ \\
\hline Cross 41/98 & 74 & $124^{\mathrm{a}}$ & $111.4^{\mathrm{abc}}$ & $7.4^{\mathrm{cd}}$ & $38^{\mathrm{b}}$ & $12.1^{\mathrm{abc}}$ & $31.5^{\mathrm{d}}$ & $4416^{\mathrm{ab}}$ \\
\hline MEAN & 78 & 119 & 110.5 & 7.6 & 37.6 & 11.9 & 38.4 & 3838 \\
\hline $\mathrm{CV} \%$ & 13 & 2.8 & 2.7 & 7.4 & 16 & 17 & 3.9 & 14 \\
\hline LSD & 18 & 6 & 5.4 & 1 & 10.7 & 3.6 & 2.6 & 962 \\
\hline Treatments & ns & $* *$ & $*$ & $* *$ & $* *$ & $*$ & $* *$ & $* *$ \\
\hline
\end{tabular}

*and $* *$ denote significant difference at $\mathrm{P}<0.05$ and $\mathrm{P}<0.01$, respectively. $\mathrm{NS}=$ Non significant. DHA=Days to heading, DMA $=\mathrm{Days}$ to maturity, $\mathrm{PLH}=\mathrm{Plant}$ height, $\mathrm{SPL}=$ Spike length, $\mathrm{SPS}=$ Seeds per spike, BMA=Biomass, TSW=Thousand seed weight and GYLD=Grain yield.

\subsection{Combined Analysis Over Location}

Over location combined analysis of variances showed that there was highly significant difference at $(\mathrm{p} \leq 0.01)$ among varieties for all yield components except days to heading. Similar results were reported by Jimera et al [10]. all agronomic parameters showed significant difference among tested varieties in the study of barley genetic variability. The results indicated that, varieties have different genetic potentials. Location also contributed significant effect on yield components for days to heading, days to maturity, plant height, spike length and thousand seed weight. The interaction of location by varieties indicated that significant effect on biomass and grain yield. The rest yield components not affected by the interaction of genotype by environment. Grain yield affected by the interaction of environment and genotype means varieties was instable across location. The average heading days ranged from 77-83 Days and minimum and maximum days was recorded on varieties HB1307 (77days), ESTAYSH and MISCAL (83days). The average maturity days ranged from 125-135 days. Shortest maturity days were recorded on AGEGNEHU (125days) and longest maturity days were recorded on EH-1493 (135Days), HB1307 (134Days) and CROSS 4198 (134Days), respectively. Average biomass ranged from 10.5-13t/ha. The lowest and highest average biomass was recorded on variety ESTAYSH (10.5t/ha) and HB-1307 (13t/ha). Finally, the tested varieties exhibited mean grain yield from 3641-4680 kg/ha. Lowest and highest mean grain yield was recorded on Local check $(3641 \mathrm{~kg} / \mathrm{ha})$ and HB-1307 (4680kg/ha), respectively. These results indicated that, late matured varieties were well performed and high yielder. Therefore, HB1307 and CROSS 41/98 recommended for pre-scale up and seed multiplication. Similarly, highest (4.8ton $\mathrm{ha}^{-1}$ ) grain yield potential was reported for HB- 1307 respectively [1].

Table 5. The mean performance of Combined analysis of yield and yield related components of food barley varieties tested at DABAT, DEBARK and WEGERA station (2014cropping season).

\begin{tabular}{|c|c|c|c|c|c|c|c|c|}
\hline \multicolumn{9}{|l|}{ Mean values } \\
\hline Varieties & DHA & DMA & PLH & SPL & SPS & BMA & TSW & GYLD \\
\hline Miscal 21 & 83 & $133^{\mathrm{a}}$ & $99^{c}$ & $8.1^{\text {bc }}$ & $29.2^{\mathrm{d}}$ & $11.1^{\mathrm{b}}$ & $48.3^{\mathrm{a}}$ & $3673^{\text {cd }}$ \\
\hline Estayish & 83 & $133^{\mathrm{a}}$ & $107.8^{\mathrm{ab}}$ & $8.4^{\mathrm{ab}}$ & $47.3^{\mathrm{a}}$ & $10.5^{\mathrm{b}}$ & $38.2^{\mathrm{c}}$ & $3533^{d}$ \\
\hline Agegnehu & 78 & $125^{\mathrm{b}}$ & $104^{\mathrm{b}}$ & $6.9^{d}$ & $38.9^{\mathrm{b}}$ & $11.1^{\mathrm{b}}$ & $38.1^{\mathrm{c}}$ & $3726^{b-d}$ \\
\hline HB1307 & 77 & $134^{\mathrm{a}}$ & $107.9^{\mathrm{ab}}$ & $7.7^{\mathrm{bc}}$ & $37.1^{\mathrm{bc}}$ & $13^{\mathrm{a}}$ & $43.7^{\mathrm{b}}$ & $4680^{\mathrm{a}}$ \\
\hline EH1493 & 79 & $135^{\mathrm{a}}$ & $106.3^{\mathrm{ab}}$ & $7.8^{\mathrm{bc}}$ & $42.7^{\mathrm{ab}}$ & $11.8^{\mathrm{ab}}$ & $37.8^{\mathrm{c}}$ & $4237^{\mathrm{a}-\mathrm{c}}$ \\
\hline Cross 41/98 & 81 & $134^{\mathrm{a}}$ & $107.9^{\mathrm{ab}}$ & $7.4^{\mathrm{cd}}$ & $38.6^{\mathrm{b}}$ & $12.2^{\mathrm{ab}}$ & $37.6^{\mathrm{c}}$ & $4259^{\mathrm{ab}}$ \\
\hline Mean & 81 & 132 & 106 & 7.9 & 37.8 & 11.6 & 41.7 & 3964 \\
\hline CV (\%) & 8.6 & 3.7 & 4.7 & 11.3 & 18 & 17 & 6.1 & 15 \\
\hline LSD & 6.6 & 5 & 5.0 & 0.86 & 6.6 & 1.9 & 2.4 & 568 \\
\hline Treatment & Ns & $* *$ & $* *$ & $* *$ & $* *$ & $* *$ & $* *$ & $* *$ \\
\hline Location & $* *$ & $* *$ & $* *$ & $* *$ & Ns & Ns & $* *$ & Ns \\
\hline Loc*Trt & Ns & Ns & Ns & Ns & Ns & $*$ & Ns & $* *$ \\
\hline
\end{tabular}

*and ** denote significant difference at $\mathrm{P}<0.05$ and $\mathrm{P}<0.01$, respectively. $\mathrm{NS}=$ Non significant. DHA=Days to heading, DMA $=$ Days to maturity, $\mathrm{PLH}=\mathrm{Plant}$ height, $\mathrm{SPL}=$ Spike length, $\mathrm{SPS}=$ Seeds per spike, BMA=Biomass, TSW=Thousand seed weight and GYLD=Grain yield. 


\section{Conclusion and Recommendations}

The analysis of variance at different locations showed a highly significant $(\mathrm{p} \leq 0.01)$ variation for the tested varieties of yield and for most of the yield related traits of food barley varieties. HB-1307 and CROSS-41/98 were the varieties with relatively high mean grain yield across locations and they are highly performing varieties to the area. HB-1307 and CROSS-41/98 showed yield advantage $28.5 \%$ and $16.9 \%$ over the local check. Therefore, those high yielder varieties are recommended for production in the tested environments and similar agro- ecologies of north Gondar zone.

\section{Authors' Contributions}

$\mathrm{AB}, \mathrm{MT}$ and ZT initiated the research, wrote the research proposal, conducted the research, did data entry and analysis and wrote the manuscript. $\mathrm{AB}$ were involved in analysis, methodology, writing, reviewing and editing of research proposal and manuscript. All authors read and approved the final manuscript.

\section{Author Details}

1 Gondar Agricultural Research Center, P. O. Box 1337, Gondar, Ethiopia.

\section{Competing Interests}

The authors declare that they have no competing interests.

\section{Availability of Data and Materials}

The authors want to declare that they can submit the data at whatever time based on your request. The datasets used and/or analyzed during the current study will be available from the corresponding author on reasonable request.

\section{Consent for Publication}

Not applicable.

\section{Ethics Approval and Consent to Participate}

Not applicable since the study involved Food barley plants.

\section{Funding}

No funding was received toward this study.

\section{Acknowledgements}

The authors would like to thank the Amhara Agricultural Research Institute, Gondar Agricultural Research Center for financing and providing working facility. We would like also to thank Debark, Dabat and Wogera district bureau of agriculture for allowing their land to accomplish the activity.

\section{References}

[1] Ayalneh Tilahun, Zerihun Jalata, Amare Biftu (2009) Registration of Guta Barley (Hordeium vulgare L.) Variety for Bale Highlands. East African Journal of Sciences 3 (1): 108110 .

[2] Berhane Lakew, Hailu Gebre, Fekadu Alemayehu (2005) Barley production and research in Ethiopia. pp. 1-8.

[3] Central Statistical Agency (CSA) Agricultural sample survey 2013 (2007 E. C.) (September to December 2009), Report on Area and Production of Crops (Private Peasant Holdings, Meher Season). Addis Ababa, Ethiopia.

[4] Chilot Yierga, Brehane Lakew and Fikadu Alemayehu, 2002. On farm evaluation of food barley production packages in the high lands of Welmera and Degem, Ethiopia. Towards farmers' participatory research: Attempts and achievements in the central highlands of Ethiopia: in proceedings of client oriented research evaluation workshop, 16-18 October 2001, Holeta Agricultural Research Center, Holeta Ethiopia. EARO.

[5] CSA, 2014, Area and Production of crops (Private peasant holdings, Meher season). Statistical Bulletin. Addis Ababa, Ethiopia.

[6] Dia M, Wehner TC, Arellano C (2016c) Analysis of genotype $x$ environment interaction (GxE) using SAS programming. Agron J 108 (5): 1838-1852.

[7] Dia M, Wehner TC, Hassell R, Price DS, Boyhan GE, et al. (2016a) Genotype x environment interaction and stability analysis for watermelon fruit yield in the U.S. Crop Sci 56: 1645-1661.

[8] Dia M, Wehner TC, Hassell R, Price DS, Boyhan GE, et al. (2016b) Values of locations for representing megaenvironment and for discriminating yield of watermelon in the US. Crop Sci 56 (4): 1726-1735.

[9] Harlan, J. R., 1969. Ethiopia: a center of diversity. Economic Botany, 23: 309-14.

[10] Jimera H., Hirpa L. and C. P. Rao (2015). Genetic Variability, Character Association and Genetic Divergence in Barley (Hordeum vulgare L.) Genotypes Grown at Horo District, Western Ethiopia Science, Technology and Arts Research Journal April-June 2015, 4 (2): 01-09

[11] Mulatu B, Grando S (2011) Barley Research and Development in Ethiopia. Proceedings of the 2nd National Barley Research and Development Review Workshop. 28-30 November 2006, HARC, Holetta, Ethiopia. ICARDA, Aleppo, Syria, pp. 391.

[12] SAS (2002). SAS/STAT user's guide, Version 9.0. SAS Institute Inc., Cary, NC.

[13] Shegaw D. Elias U. and Hussein M. (2013). Genetic Variability in Barley (Hordeum vulgare (L.)) Landrace Collections from Southern Ethiopia. International Journal of Science and Research (IJSR). 
[14] Tahir M, Tanveer A, Ali A, Abbas M, Wasaya A (2008) Comparative yield performance of different maize (Zea Mays $L$.) Hybrids under local conditions of Faisalabad-Pakistan. Pak J Life Soc Sci 6: 118-120.
[15] Von Bothmer R, Sato K, Komatsuda T, Yasuda S, Fischbeck G (2003) The domestication of cultivated barley. In: von Bothmer R, van Hintum T, Knüpffer H, Sato K (eds) Diversity in barley (Hordeum vulgare). Elsevier Science B. V., Amsterdam, pp 9-27. 